\title{
Boron Uptake and Effects on Growth and Carbohydrate Partitioning of Pistachio Seedlings
}

\author{
G.A. Picchioni ${ }^{1}$ and S. Miyamoto ${ }^{2}$ \\ Texas A\&M University Agrcultural Research and Extension Center, 1380 A\&M Circle, El Paso, \\ TX 79927
}

J.B. Storey
Department of Horticultural Sciences, Texas A\&M University, College Station, TX 77843-2133

Additional index words. Pistacia spp., rootstock, nutrition, B toxicity, sugars, starch, translocation, carbon allocation

Abstract. Seedlings of three pistachio rootstock (Pistacia atlantica Desf., P. terebinthus L., and P. integerrima Stewart $\times$ atlantica) and of the pistachio scion cultivar Kerman $(P$. vera. L.) were grown in calcareous sandy loam irrigated with B solutions (0 to $\left.15 \mathrm{mg} \cdot \mathrm{liter}^{-1}\right)$ in a greenhouse. After 10.5 months of B treatment, rootstock seedling growth (root + stem weight and leaf dry weight, area, and number per plant) had decreased linearly with B application, which provided up to $48.9 \mathrm{mg} \mathrm{B} /$ liter in the soil saturation extract. Growth of $P$. terebinthus was greater than $P$. atlantica throughout the concentration range, but species sensitivity to B did not differ. Nine months of B at concentrations up to $10.7 \mathrm{mg} \cdot$ liter $^{-1}$ in the saturation extract did not alter the growth of $P$. vera seedlings. Leaf B concentrations of all species increased linearly with saturation extract B concentration after each of two growing periods and were higher in leaves of $P$. terebinthus than $P$. atlantica. From $62 \%$ to $75 \%$ of $\mathrm{B}$ was present in leaf tissue of the rootstock seedlings, with lower quantities in roots and stems. Boron toxicity appeared initially as interveinal chlorosis and apical necrosis of 1-month-old, fully expanded leaflets of the rootstock species. By 4 months, symptoms in some treatments advanced to severe necrosis of leaflets. Boron addition increased the concentrations of total leaf sugars (glucose, fructose, and sucrose) and root starch, decreased root glucose concentrations, and had no effect on other root carbohydrates of $P$. vera seedlings. Leaf carbohydrate supply limitations and altered root carbohydrate status may be consequences of high B in $P$. vera seedling leaves.

The presence of excess $\mathrm{B}$ in soils and irrigation waters has been a persistent concern in irrigated areas of the western United States (Mikkelsen et al., 1988; Wilcox, 1948). However, data on high B responses of pistachio, an important tree crop of the area, are limited. A greenhouse study established a high correlation between $\mathrm{B}$ concentration in soils and in leaves of some Iranian pistachio cultivars, but a concentration producing growth reduction was not determined (Parsa and Wallace, 1980b). Ashworth et al. (1985) imply a relationship between leaf marginal necrosis of $P$. vera 'Kerman' and high accumulation of B. We could find no data on pistachio seedling rootstock responses to excess $\mathrm{B}$ in soil solutions. The identification of growth and B uptake characteristics is essential for selecting seedling rootstock suitable for high B soils. For example, differences in B uptake were observed with citrus rootstocks (Cooper et al., 1955) and tomato cultivars (Brown and Jones, 1971).

There is also limited knowledge of plant metabolic dysfunctions resulting from B excess (Francois, 1986). Supraoptimal tissue B levels may alter the structure or function of the phloem (Canny, 1973; Epstein, 1973), which might be expected to impede the mobilization of soluble metabolizes.

This study evaluated the effects of high B on the growth and B uptake of Pistacia spp. rootstock seedlings and on the carbohydrate status of $P$. vera seedlings.

Received for publication 3 Mar. 1990. Contribution from the Texas Agricultural Experiment Station and supported in part by the Expanded Research Area Fund of the Experiment Station. Appreciation is extended to Henry O. Mollner, Arizona Pistachio Corp., and R.R. Walker, CSIRO, Merbein, Victoria, Australia, for donating seed for this project. The cost of publishing this paper was defrayed in part by the payment of page charges. Under postal regulations, this paper therefore must be hereby marked advertisement solely to indicate this fact.

'Thomas B. Slick Graduate Research Fellow. Present address: Dept. of Pomology, Univ. of California, Davis, CA 95616.

${ }^{2}$ Professor of Soil and Water Science.

${ }^{3}$ Professor of Horticultural Sciences.

\section{Materials and Methods}

General methods Two greenhouse studies were made between May 1986 and June 1988 using seedlings of three rootstock species and a scion cultivar. The seedlings were cultured in plastic pots containing the A horizon of Hueco sandy loam (calcareous, coarse silty, mixed, thermic, petrocalcic Paleargid). In both studies, the lower half of the pots was filled with soil that had been pretreated with dissolved boric acid solution to complement the sorption deficit according to the method of Ryan et al. (1977). During the experiments, B was applied to the soil through irrigation (boric acid in tap water) at the following concentrations: trace B (tap water only), 2.5, 5.0, 7.5, 10.0 , and $15.0 \mathrm{mg} \cdot$ liter $^{-1}$. All irrigation solutions contained 0.66-strength Hoagland nutrient solution \#1 without B (Hoagland and Arnon, 1950; Parsa and Wallace, 1980a). The tap water control contained $\approx 0.2 \mathrm{mg} B /$ liter. Solutions were applied in amounts to cause a 0.45 to 0.55 leaching fraction (drainage/ application volume) when the soil moisture in the pots, measured gravimetrically, was depleted to $0.15 \mathrm{~m}^{3} \cdot \mathrm{m}^{-3}$, or half of the total storage capacity. The greenhouse was maintained between $16 \mathrm{C}$ at night and $32 \mathrm{C}$ during the day. For winter months, the daytime maximum was reduced to $27 \mathrm{C}$.

At the end of B treatments, harvested seedlings were separated into leaves, stems, and roots. Total leaf number and fresh weight of roots plus stem were determined after washing soil from roots. Total leaf area was measured using a portable area meter (LI-COR 3000; LI-COR, Lincoln, Neb. ). For B analyses, all leaves (fully expanded with petioles) were cleaned, dried, weighed, and ground (Picchioni et al., 1990). Subsamples $(0.25$ to $0.50 \mathrm{~g})$ were ashed in a muffle furnace for 12 $\mathrm{h}$ at $550 \mathrm{C}$, then $\mathrm{B}$ was extracted from the ash using $6 \mathrm{~N} \mathrm{HCl}$ (Hatcher and Wilcox, 1950) and measured using a plasma emission spectrometer (Applied Research Laboratories, Sunland, Calif.).

Soil saturation extract B concentrations (Richards, 1954) were measured in each pot of each trial, as described above, midway 
and at the end of each experimental period. The average of the two readings represented soil B concentrations.

Rootstocks (Expt. 1). Seedlings of P. atlantica (PI 246336), $P$. terebinthus (PI 246341), and P. integerrima $\times$ atlantica $(\mathrm{PG}$ II) were prepared as described by Picchioni et al. (1990). Following a 2 -month growing period in the greenhouse, seedling tops were 10 to $15 \mathrm{~cm}$ tall ( $\approx 2 \mathrm{~g}$ seedling fresh weight). Seedlings then were planted 30 May 1986 into 12-liter pots at the rate of four per pot (two each of $P$. atlantica and $P$. terebinthus). Because of a limited supply, PG II seedlings were planted individually in separate pots with three buffer seedlings of $P$. terebinthus and were exposed only to 5,10 , and $15 \mathrm{mg} \mathrm{B} / \mathrm{liter}$ irrigation solutions. Previous data showed that PG II seedlings had a higher growth rate than $P$. atlantica and $P$. terebinthus (Picchioni et al., 1990); thus, we were primarily interested in the B uptake characteristics of this hybrid.

Boron treatments began 14 July; on 1 Nov., pots were moved to an unheated shadehouse to impose dormancy. On 5 Jan., leaves from trace, 5, 10, and $15 \mathrm{mg}$ B/liter irrigation treatments were collected and pooled separately to allow sufficient dry weight for B analyses. On 2 Feb., defoliated plants were returned to the greenhouse, irrigated with B solutions during the second growth period, and prepared for analyses 1 June (10.5 month treatment). Stems and roots (woody and nonwoody) of three replicate seedlings of the $10 \mathrm{mg}$ B/liter irrigation solution were also dried, ground, and analyzed for B as described for leaves.

Scion cultivar (Expt. 2). Seed of P. vera 'Kerman' were stratified 6 weeks in perlite at 5C, then planted 10 July 1987 in 8-liter pots. Boron treatments (identical to Expt. 1) began 31 Aug. after thinning to one seedling per pot (tops 10 to $15 \mathrm{~cm}$ tall, $\approx 5 \mathrm{~g}$ seedling fresh weight). On $17 \mathrm{Feb}$., leaves were $\approx 5.5$ months old and were collected for B analyses for the first growing period. Boron treatments were maintained, and a second shoot growth period began within 2 weeks. By 1 Apr., terminal buds had formed and most leaves were fully expanded. Treatments were stopped on 7 June (9-month treatment); at midday, $P$. vera seedlings grown with trace, 5 , and $15 \mathrm{mg} \mathrm{B} /$ liter irrigation solutions were harvested (second growth period). After recording root plus stem weight, three to four basal leaves, located at about the bottom one-third of the stem axes, and detached root systems were rinsed with distilled water, dried with paper towels, and preserved for carbohydrate determination by a method modified from Weimberg (1987) and Crane et al. (1976). Tissues were placed initially in a drying oven at $105 \mathrm{C}$ for $30 \mathrm{~min}$, followed by $60 \mathrm{C}$ to constant dryness. Preliminary tests showed that tissue sugar concentrations were not significantly altered using this method (Picchioni, 1989). After drying, basal leaf weight was added to that of the remaining leaves to obtain a total dry weight. Boron analyses were also made on the basal leaves of this growing period.

Fine roots $(<2 \mathrm{~mm}$ in diameter) were separated from the dry root masses and analyzed along with basal leaves for carbohydrates and B. Tissues were ground as above and stored in sealed jars at $-25 \mathrm{C}$. Subsamples $(0.50 \mathrm{~g})$ were extracted for glucose, fructose, and sucrose four times (20 min each) in boiling ethanol $(10 \mathrm{ml}, 80 \% \mathrm{v} / \mathrm{v})$ with refluxing (McBee et al., 1983). Starch was hydrolyzed from the ethanol-insoluble material following 24-h incubation at 38C (Na-acetate buffer, $\mathrm{pH} 4.6$ ) with amyloglucosidase (Sigma, St. Louis). The residue was then extracted three times ( 5 min each) in 60C water. Five-milliliter aliquots of all extracts were passed through $0.45-\mu \mathrm{m}$ membrane filters to remove particulate matter, stored at $5 \mathrm{C}$, and analyzed within $24 \mathrm{~h}$.

Determination of sugars and starch (after hydrolysis) was made using a spectrophotometer at $340 \mathrm{~nm}$ (Spectronic $21 \mathrm{UV}-\mathrm{D}$; Bausch and Lomb, Rochester, N. Y.) according to the enzymatic method outlined by Sturgeon (1990). Enzymes for the assays were obtained from Boehringer Mannheim (Indianapolis). Recovery of known sugars added before extraction of leaf samples averaged $99.8 \%$ and $98.5 \%$ as internal standards in assays of ethanol extracts (average $\mathrm{CV}=3.7 \%$ ).

Statistical analyses. Pots of Expt. 1 were arranged in a split plot, with B solution concentrations (main plot) randomized completely within each of five blocks. The subplots (rootstock species) were the average of two seedlings of $P$. atlantica and $P$. terebinthus per pot and one for PG II. The analysis of variance was made for the split plot according to Little and Hills (1978), excluding PG II seedling data. Experiment 2 was a oneway randomized complete block with two to three, four, or five replicates ( $\mathrm{B}$, carbohydrate, and growth analyses, respectively).

Orthogonal contrasts were partitioned from the main effects of B saturation extract values using polynomials for unequally spaced treatments (F.J. Hills, personal communication). Linear regressions were evaluated by slope and intercept comparisons (Snedecor and Cochran, 1989) using MSTAT-C statistical software (Michigan State Univ., East Lansing). In both studies, the B concentrations reported are those measured in the soil saturation extract.

\section{Results}

Seedling growth. Boron application decreased seedling growth of $P$. atlantica and $P$. terebinthus significantly (Table 1), with linear contrasts accounting for $74 \%$ to $86 \%$ of the B treatment variation (higher order contrasts were not significant). On average, the growth of $P$. terebinthus was 1.3 to 2.4 times greater than $P$. atlantica, depending on growth characteristic, with significantly greater intercepts in each comparison. However, there were no significant differences in species sensitivity to increasing saturation extract B concentration (decreasing slopes) with any of the growth characteristics. Root plus stem growth of $P$. terebinthus was highly variable at low B concentrations, particularly in controls $(\mathrm{CV}=48 \%)$. In addition, mean growth of roots plus stem changed inversely between the species with each increase in B concentration. These factors contributed to the B $X$ rootstock interaction, even though the slopes were nearly identical. Fresh root plus stem weight consisted of $\approx 70 \%$ roots (data not shown); thus, B effects were attributed mainly to root growth reduction.

At high $\mathrm{B}$, the combined leaf dry weight averages declined $74 \%$ below controls. This reduction resulted mostly from a decrease in leaf number per seedling (53\% reduction), with parallel losses in measured leaf area (54\%). Specific leaf weights and leaf area per leaf were unaffected by B application (data not shown). Leaf area measurements included necrotic tissue at $20.9 \mathrm{mg} \mathrm{B} /$ liter in the saturation extract and higher; thus, functional leaf area was reduced more than the data indicate.

In Expt. 2, saturation extract B up to $10.7 \mathrm{mg} \cdot \operatorname{liter}^{-1}$ (15 $\mathrm{mg} \cdot$ liter $^{-1}$ irrigation solution) did not reduce leaf dry weight, size, total area, root fresh weight, or root plus stem fresh weight of $P$. vera seedlings (data not shown). Final height of seedling tops ranged from 50 to $60 \mathrm{~cm}$, and root plus stem fresh weight . from 60 to $70 \mathrm{~g}$.

Boron toxicity symptoms. There were no foliar disorders on 
Table 1. Growth responses of $P$. atlantica and $P$. terebinthus rootstock seedlings to increasing $B$ concentrations in the soil saturation extract (Expt. 1, second growing period). Irrigation solutions containing trace, $2.5,5.0,7.5,10.0$, or $15.0 \mathrm{mg} \mathrm{B} /$ liter correspond to increasing saturation extract B concentrations.

\begin{tabular}{|c|c|c|c|c|}
\hline $\begin{array}{c}\text { Mean saturation } \\
\text { extract B } \\
\left(\mathrm{mg} \cdot \text { liter }^{-1}\right)^{\mathrm{z}}\end{array}$ & $\begin{array}{c}\text { Root }+ \text { stem } \\
\text { fresh wt } \\
(\mathrm{g})\end{array}$ & $\begin{array}{l}\text { Leaf dry wt } \\
(\mathrm{g})\end{array}$ & $\begin{array}{c}\text { Total leaf } \\
\text { area } \\
\left(\mathrm{cm}^{2}\right) \\
\end{array}$ & Leaves/plant \\
\hline \multicolumn{5}{|c|}{ P. atlantica } \\
\hline 3.0 (control) & 31.0 & 1.5 & 98.1 & 23.7 \\
\hline 15.5 & 17.6 & 1.0 & 67.9 & 16.1 \\
\hline 20.9 & 19.6 & 1.2 & 79.8 & 20.3 \\
\hline 25.2 & 22.5 & 0.8 & 54.2 & 13.7 \\
\hline 44.7 & 15.6 & 0.7 & 45.6 & 11.9 \\
\hline 48.9 & 17.0 & 0.5 & 27.6 & 9.3 \\
\hline \multicolumn{5}{|c|}{ P. terebinthus } \\
\hline 3.0 (control) & 27.5 & 2.7 & 187.4 & 28.8 \\
\hline 15.5 & 40.3 & 3.0 & 209.9 & 24.2 \\
\hline 20.9 & 34.3 & 2.3 & 151.6 & 29.6 \\
\hline 25.2 & 22.7 & 3.3 & 224.5 & 36.0 \\
\hline 44.7 & 26.1 & 1.7 & 122.7 & 21.0 \\
\hline 48.9 & 13.0 & 0.6 & 102.8 & 15.6 \\
\hline \multicolumn{5}{|l|}{ Significance } \\
\hline B solution & $\mathrm{L}^{* *}$ & $\mathrm{~L}^{* *}$ & $\mathrm{~L}^{* *}$ & $\mathrm{~L}^{* *}$ \\
\hline Rootstock & $* *$ & $* *$ & $* *$ & $* *$ \\
\hline Rootstock $\times$ B & $*$ & NS & NS & NS \\
\hline
\end{tabular}

${ }^{z}$ Values are the means of five replicates, each the average of two seedlings per species.

${ }^{* *, *, N S}$ Linear (L); significant at $P=0.01,0.05$, or nonsignificant at $P=0.05$, respectively.

the rootstock seedlings after the first growing period, although some leaves contained up to $2000 \mathrm{mg} \mathrm{B} / \mathrm{kg}$ dry weight. By January, all leaves had senesced. One month after resumption of B application in Expt. 1 (2 Mar.), interveinal chlorosis and tip necrosis appeared on fully expanded leaflets at $20.9 \mathrm{mg} \mathrm{B} /$ liter in the saturation extract. Leaves $<1$ month old were not visibly affected. By 1 June, most sampled leaves were $\approx 4$ months old, and toxicity symptoms had progressed to marginal and interveinal necrosis, affecting a greater proportion of leaves, which increased with B application. On average, necrosis was present on $47 \%$ of $P$. terebinthus leaflets from seedlings exposed to $20.9 \mathrm{mg} \mathrm{B} /$ liter and higher in the saturation extract, compared to only $30 \%$ for $P$. atlantica, although this difference was highly variable. Boron-affected seedling leaves contained $>1300 \mathrm{mg}$ $\mathrm{B} / \mathrm{kg}$ dry weight, but toxicity was not observed with leaf concentrations $<1000 \mathrm{mg} \cdot \mathrm{kg}^{-1}$.

With $P$. vera leaves, chlorosis and tip necrosis did not appear initially, although some marginal necrosis was evident on seedlings exposed to $5.3 \mathrm{mg} \mathrm{B} /$ liter in the saturation extract after the first growing period ( 17 Feb.). These leaves contained $\geq 1200$ $\mathrm{mg} \mathrm{B} / \mathrm{kg}$ and were $\approx 5.5$ months old at the bottom third of the stem axes. With $10.7 \mathrm{mg} \mathrm{B} /$ liter in the saturation extract, slight marginal necrosis was observed on 99-day-old leaves ( $\approx 2500$ $\mathrm{mg} \mathrm{B} / \mathrm{kg}$ ) from the second growing period (7 June), whereas no disorders were, observed with lower B rates. Necrotic areas comprised $<5 \%$ of the total leaf weight at sampling.

Tissue B concentrations. Linear contrasts accounted for $94 \%$ to $97 \%$ of the B effect on leaf B concentrations of P. atlantica, $P$. terebinthus, and $P$. vera. After the first growing period, B levels in rootstock seedling leaves ( $\approx 5$ months old, pooled samples) had increased linearly with B treatment $\left(R^{2}=0.88\right.$ to 0.94 ) and reached as high as $2000 \mathrm{mg} \cdot \mathrm{kg}^{-1}$, but were not species-dependent (data not shown). However, with further B ap- plication, leaf B of $P$. terebinthus increased at a significantly higher rate $(P=0.05)$ than that of $P$. atlantica following the second growth period (Fig. 1). When all three species were compared, only in 5-, 10-, and 15-mg-liter ${ }^{-1}$ irrigation treatments ( $\mathrm{n}=12-20$ at common saturation extract $\mathrm{B}$ levels) were there no regression differences, and there was a poor correlation for PG II ( $\left.R^{2}=0.09\right)$. However, $P$. atlantica and PG 11 had similar slopes (49.5 and 36.3, respectively), with $P$. terebinthus much higher (98.0).

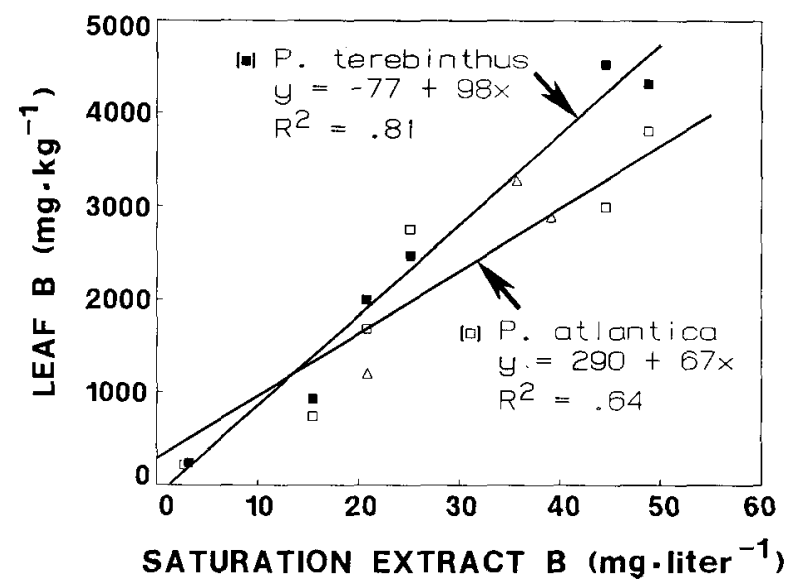

Fig. 1. Leaf B concentrations (dry-weight basis) of Pistacia spp. seedling rootstock (Expt. 1) as affected by B in the soil saturation extract. The line for PG II points (open triangles) is not included. Data are mean values of five replicates for leaf and saturation extract $\mathrm{B}$ concentrations after the second growing period. Regression data shown for 28 observations per species. (At $48.9 \mathrm{mg} \mathrm{B} /$ liter in the saturation extract, leaves of two replicates of each species provided insufficient dry weight for B analysis.) 
Boron concentrations in leaves of $P$. vera were markedly higher than those in the rootstock species at equivalent saturation extract B levels (Fig. 2). Leaf B concentrations increased at a higher rate during the second growing period $(P=0.05)$, which may have resulted from the long-day conditions compared to short days for the first growing period. However, this difference was observable only at the highest B concentration.

The percentage of total plant $\mathrm{B}$ in seedling organs (the product of organ dry weight and the corresponding B concentration) was highest in leaves, with much smaller but similar values in roots and stems (Table 2). PG II contained the lowest percent total plant B in leaves, but there was no rootstock effect on B quantity in nonfoliar portions. Boron concentrations in roots and stems (rootstock averages) were 252 and $271 \mathrm{mg} \cdot \mathrm{kg}^{-1}$, respectively.

There were also much smaller B concentrations in nonwoody $P$. vera roots on the final sampling date, despite the large increases in leaf B (root averages of 77, 193, and $289 \mathrm{mg} \cdot \mathrm{kg}^{-1}$ for $0.4,3.9$, and $10.7 \mathrm{mg} \mathrm{B/liter} \mathrm{saturation} \mathrm{extract} \mathrm{concentra-}$ tions, respectively). Lower B concentrations were found in woody roots (data not shown).

Carbohydrate levels. Boron applications altered the balance of carbohydrates in leaf and root tissues of $P$. vera without affecting total carbohydrates measured (Table 3 ). Raising the $\mathrm{B}$ concentration in the saturation extract resulted in a linear in-

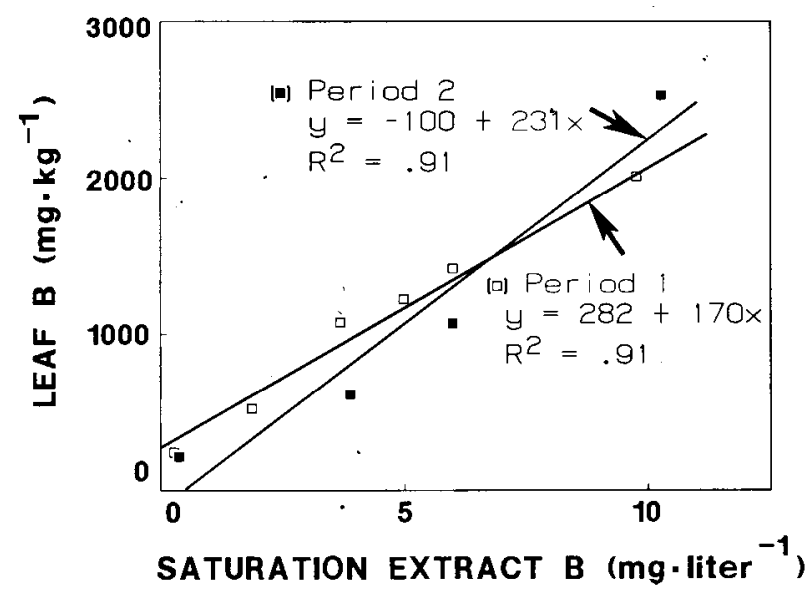

Fig. 2. Leaf B concentrations of $P$. vera 'Kerman' seedlings (Expt.

2) after the first and second growing periods, expressed as in Fig.

1. Data are mean values of two to three replicates for leaf and saturation extract B concentrations. Regression data shown for 18 and nine observations for periods 1 and 2, respectively. For period 2, leaf B only for $0.4,3.9,6.0$, and $10.3 \mathrm{mg} \cdot$ liter $^{-1}$ saturation extract $\mathrm{B}$ levels are included.

Table 2. Partitioning of B among seedling tissues of Pistacia spp. rootstock with $10 \mathrm{mg} \mathrm{B/liter} \mathrm{in} \mathrm{the} \mathrm{irrigation} \mathrm{solution} \mathrm{(Expt.} \mathrm{1,}$ second growing period). Soil saturation extract B concentrations (mg.liter ${ }^{-1}$ ) were $44.5 \pm 6.9$ (P. atlantica and P. terebinthus) and $39.2 \pm 8.6(\mathrm{PG}$ II).

\begin{tabular}{lccc}
\hline \hline & \multicolumn{3}{c}{ B distribution (\%) } \\
\cline { 2 - 4 } Rootstock $^{\mathrm{z}}$ & Leaves & Stems & Roots \\
\hline$P$. atlantica & $75 \mathrm{a}$ & $14 \mathrm{a}$ & $11 \mathrm{a}$ \\
$P$. terebinthus & $74 \mathrm{a}$ & $11 \mathrm{a}$ & $15 \mathrm{a}$ \\
PG II & $62 \mathrm{~b}$ & $20 \mathrm{a}$ & $18 \mathrm{a}$ \\
\hline
\end{tabular}

${ }^{\mathrm{z}}$ Mean separation in columns by Duncan's multiple range test $(P=$ $0.05)$.

${ }^{y}$ Values are the averages of three or five seedling replicates (nonfoliar and foliar portions, respectively) calculated as organ dry weight $(\mathrm{kg})$ $\times \mathrm{B}$ concentration $\left(\mathrm{mg} \cdot \mathrm{kg}^{-1}\right.$ dry weight)/total seedling B $(\mathrm{mg}) \times 100$. crease in leaf sucrose concentration. Total leaf sugars increased $54 \%$ with $10.7 \mathrm{mg} \mathrm{B} /$ liter in the saturation extract, even though changes in concentrations of reducing sugars in leaves were inconsistent.

High B also caused a significant increase in the ratio of leaf : root sugars (1.0 vs. 0.5 in controls), whereas $3.9 \mathrm{mg}$ B/liter in the saturation extract had no effect (data not shown). Linear but opposite B effects on root glucose and starch levels were greatest at $3.9 \mathrm{mg} \mathrm{B} / \mathrm{liter}$, followed by marginal changes with $10.7 \mathrm{mg} \cdot \mathrm{liter}^{-1}$. Control roots had 54\% lower starch and 64\% higher glucose concentrations than high-B-treated roots.

\section{Discussion}

Although $20.9 \mathrm{mg} \mathrm{B} /$ liter in the saturation extract caused prolonged leaflet necrosis of $P$. atlantica and $P$. terebinthus seedlings, higher B concentrations were required to bring about observable root plus stem growth reductions when averaged for both species. This observation is similar to a report of B-affected. barley (Hordeum vulgare L.) seedlings in which B toxicity symptoms were expressed before shoot and root weights decreased (Riley, 1987). Leaf weights seemed to be more B-sensitive than root plus stem weights (reductions of $74 \%$ vs. $48 \%$ for high $\mathrm{B}$, respectively), which may ultimately affect total plant weight with longer treatment duration or in environments of higher evaporative demand, which intensify the movement of B to leaves (Oertli and Kohl, 1961). The greenhouse relative humidity rarely dropped below $23 \%$, whereas in outdoor conditions of far-western Texas, midday relative humidity is frequently less than half of this value during the growing season.

There were no B effects on shoot elongation rates or shoot mortality after the first growing period of Expt. 1 (data not shown), indicating that reductions in leaf weight and number were caused only after sufficient duration of B treatment (10.5 months) by the end of the second growing period. In an earlier study, we found that after 8 months, saturation extract $\mathrm{B} \geq 3$ $\mathrm{mg} \cdot$ liter $^{-1}$ caused death of axillary and terminal buds of young pecan trunks [Carya illinoensis (Wangenh.) C. Koch], which limited new shoot and leaf production (Picchioni et al., 1991).

The differences in B uptake and distribution patterns between PG II, $P$. atlantica, and $P$. terebinthus may be important for high $\mathrm{B}$ soils. However, we are uncertain whether the higher rate of increase in seedling leaf B concentrations of $P$. vera compared to the rootstock seedlings reflects inherent characteristics or differences in experimental conditions. These findings indicate that further study is needed to determine whether the rootstock can alter B accumulation rates of $P$. vera scion leaves in high $\mathrm{B}$ areas.

The linear relationship between leaf $\mathrm{B}$ and saturation extract B in Expts. 1 and 2 indicates that seedling B status of these species can be assessed by leaf or saturation extract B measurements. Also, B concentrations $\geq 1200 \mathrm{mg} \cdot \mathrm{kg}^{-1}$ in 3 - to 6month-old leaves were well correlated with toxicity occurrence during both studies. Ashworth et al. (1985) found slightly less $\mathrm{B}\left(\approx 1000 \mathrm{mg} \cdot \mathrm{kg}^{-1}\right)$ in necrotic, B-affected leaves of $P$. vera trees at the end of a growing season. Saturation extract B increased linearly with B in the irrigation solutions, but soil B characteristics differed greatly between Expts. 1 and 2. This difference may have resulted from variation in leaching fractions between the studies. Minor variation in leaching water volume can greatly affect soluble soil B levels in the range of leaching fractions used in this study (Keren and Miyamoto, 1990).

Raven (1980) suggested that limited mobility of B is associated with toxicity of this element in the phloem. The injury 
Table 3. Carbohydrate concentrations (dry-weight basis) of P. vera 'Kerman' seedlings as affected by B in the soil saturation extract (Expt. 2, second growing period). Irrigation solutions containing trace, 5 , and $15 \mathrm{mg} \mathrm{B} / \mathrm{liter}$ correspond to increasing saturation extract B concentrations.

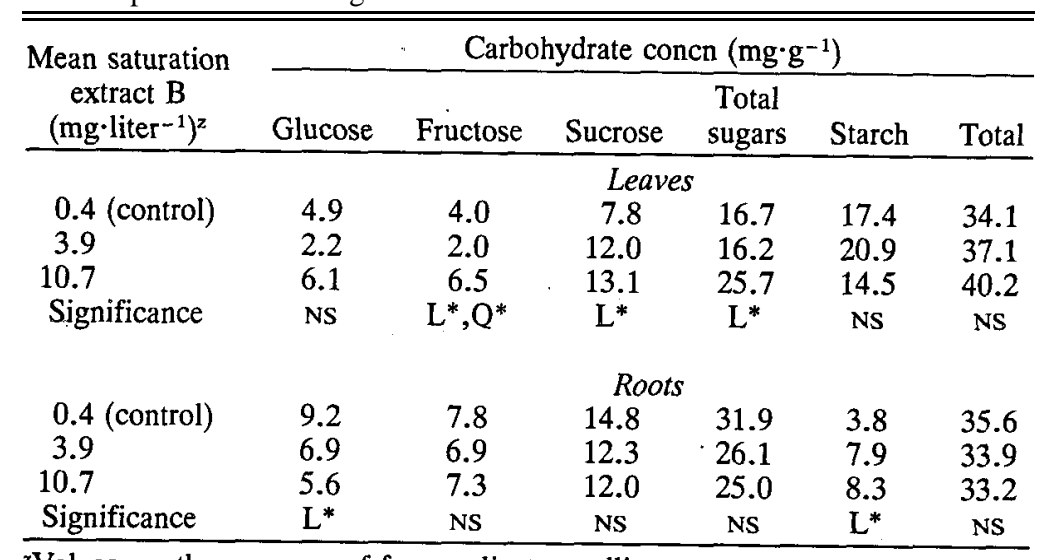

${ }^{z}$ Values are the averages of four replicate seedlings.

*,NSLinear (L), quadratic $(\mathrm{Q})$; significant or nonsignificant at $P=0.05$, respectively.

is suggested to occur in sieve plate areas (Canny, 1973; Epstein, 1973), even though this depends on the duration of high B status (Van de Venter and Currier, 1977). McNairn and Currier (1965) found that excessive callose accumulation was a sensitive indicator of $\mathrm{B}$ excess in bean leaves (Phaseolus vulgaris L.). In their study, callose-like deposits first appeared in mesophyll cells, followed by high quantities in sieve plates, which may restrict the movement of materials in the phloem (Currier, 1957; McNairn and Currier, 1965). This restriction maybe related, in part, to the increasing leaf sucrose values found in our study. Sucrose has been identified as the dominant sugar in bark of current-season shoots of P. vera 'Bronte' (Crane et al., 1976).

Another possibility explaining impaired export of leaf sugars relates to adverse osmotic effects at transpirational termini, where B accumulation would be greatest (Bussler, 1981). According to the mass-flow hypothesis, Maas and Nieman (1978) suggest that photosynthate accumulation in salt-affected leaves may partly result from diminished solute potential in regions other than vein endings. Oertli (1968) estimated that the solute potential of boric acid in a leaf can be as low as $-0.2 \mathrm{MPa}$ if confined to the free space. We calculated that boric acid concentrations in the free space solution of $\mathrm{B}$-affected $P$. vera leaves (containing $>1200 \mathrm{mg} \mathrm{B} / \mathrm{kg}$ dry weight) could have exceeded $300 \mathrm{~mm}$, assuming B was present as boric acid (Oertli and Grgurevic, $1975)$ in the free space volume occupying a maximum tissue volume of $20 \%$ (Noggle and Fritz, 1976). This estimate would be larger when considering only the leaf margins where B typically accumulated.

A reduced supply of carbohydrates from B-affected leaves could have altered sink demand and carbon pools in roots, where starch increased as glucose decreased with leaf B concentration. A direct influence of B on roots should not be discounted, since Klein and Brown (1982) showed that high B arrests mitosis (thus carbon use) in pea (Pisum sativum L.) root tips. However, root plus stem growth reduction in Expt. 1 occurred with root B concentrations similar to those in Expt. 2 (with no root growth reductions), but with higher overall leaf $\mathrm{B}$ concentrations. Thus, a direct effect of $\mathrm{B}$ in leaves, followed by alterations in root carbohydrate status, and ultimately growth of roots seem to be consequences of high leaf B concentrations in these seedlings. Since $P$. vera root growth was unaffected, younger leaves that accumulated less B may have supplied carbohydrates normally supplied by the older, basal leaves to maintain sufficient physiological levels in roots.

Additional work is necessary to evaluate the effects of longterm, recurring high $\mathrm{B}$ conditions on growth and carbohydrate status of bearing pistachio trees. High leaf B concentrations, for example, may further alter carbohydrate status of trees with competing, reproductive sinks.

\section{Literature Cited}

Ashworth, L.J., Jr., S.A. Gaona, and E. Surber. 1985. Nutritional diseases of pistachio trees: Potassium and phosphorus deficiencies and chloride and boron toxicities. Phytopathology 75:1084-1091.

Brown, J.C. and W.E. Jones. 1971. Differential transport of boron in tomato (Lycopersicon esculenium Mill.). Physiol. Plantarum 25:279282.

Bussler, W. 1981. Microscopical possibilities for the diagnosis of trace element stress in plants. J. Plant Nutr. 3:115-128.

Canny, M.J. 1973. Phloem translocation. Cambridge Univ., New York.

Cooper, W. C., A. Peynado, and A.V. Shun. 1955. Boron accumulation in citrus as influenced by rootstock. J. Rio Grande Valley Hort. Soc. 9:86-94.

Crane, J.C., P.B. Catlin, and I. Al-Shalan. 1976. Carbohydrate levels in the pistachio as related to alternate bearing. J. Amer. Soc. Hort. Sci. 101:371-374.

Currier, H.B. 1957. Callose substance in plant cells. Amer. J. Bot. 44:478-488.

Epstein, E. 1973. Flow in the phloem and the immobility of calcium and boron: A new hypothesis in support of an old one. Experientia 29:133-134.

Francois, L.E. 1986. Effect of excess boron on broccoli, cauliflower, and radish. J. Amer. Soc. Hort. Sci. 111:494-498.

Hatcher, J.T. and L.V. Wilcox. 1950. Calorimetric determination of boron using carmine. Anal. Chem. 22:567-569.

Hoagland, D.R. and D.I. Arnon. 1950. The water-culture method of growing plants without soil. Calif. Agr. Expt. Sta. Circ. 347.

Keren, R. and S. Miyamoto. 1990. Reclamation of saline, sodic, and boron-affected soils, p. 410-431. In: K.K. Tanji (ed.). Agricultural salinity assessment and management. Amer. Soc. Civil Eng., New York.

Klein, R.M. and S.J. Brown. 1982. Effect of borate excess and calcium ion on mitosis of pea root-tip meristem cells. Env. Expt. Bot. 22:199202. 
Little, T.M. and F.J. Hills. 1978. Agricultural experimentation. Wiley, New York.

Maas, E.V. and R.H. Nieman. 1978. Physiology of plant tolerance to salinity, p. 277-299. In: G.A. Jung (ed.). Crop tolerance to suboptimal land conditions. Amer. Soc. Agron. Spec. Publ. 32.

McBee, G.G., R.M. Waskom, III, F. R., Miller, and R.A. Creelman. 1983. Effect of senescence and nonsenescence on carbohydrates in sorghum during late kernel maturity states. Crop Sci. 23:372-376.

McNairn, R.B. and H.B. Currier. 1965. The influence of boron on callose formation in primary leaves of Phaseolus vulgaris L. Phyton 22:153-158.

Mikkelsen, R.L., G.H. Haghnia, A.L. Page, and F.T. Bingham. 1988 The influence of selenium, salinity, and boron on alfalfa tissue composition and yield. J. Env. Quality 17:85-87.

Noggle, G.R. and G.J. Fritz. 1976. Introductory plant physiology. Prentice-Hall, Englewood Cliffs, N.J. p. 322.

Oertli, J.J. 1968. Extracellular salt accumulation, a possible mechanism of salt injury in plants. Agrochimica 12:461-469.

Oertli, J.J. and H.C. Kohl. 1961. Some considerations about the tolerance of various plant species to excessive supplies of boron. Soil Sci. 92:243-247.

Oertli, J.J. and E. Grgurevic. 1975. Effect of $\mathrm{pH}$ on the absorption of boron by excised barley roots. Agron. J. 67:278-280.

Parsa, A.A. and A. Wallace. 1980a. Effect of strength of nutrient solution on the growth and nutrient uptake of pistachio seedlings. J. Plant Nutr. 2:257-261.

Parsa, A.A. and A. Wallace. 1980b. Differential partitioning of boron and calcium in shoots of seedlings of two pistachio cultivars. J. Plant Nutr. 2:263-266.

Picchioni, G.A. 1989. Growth, ion uptake, and some metabolic processes of Pistacia spp. affected by salinity and boron. PhD Diss., Texas A\&M Univ., College Station.

Picchioni, G.A., S. Miyamoto, and J.B. Storey. 1990. Salt effects on growth and ion uptake of pistachio rootstock seedlings. J. Amer. Soc. Hort. Sci. 115:647-653.

Picchioni, G.A., S. Miyamoto, and J.B. Storey. 1991. Growth and boron uptake of five pecan cultivar seedlings. HortScience 26:386388.

Raven, J.A. 1980. Short- and long-distance transport of boric acid in plants. New Phytol. 84:231-249.

Richards, L.A. (ed.). 1954. Diagnosis and improvement of saline and alkali soils. U.S. Dept. Agr. Hdbk. 60.

Riley, M.M. 1987. Boron toxicity in barley. J. Plant Nutr. 10:21092115.

Ryan, J., S. Miyamoto, and J. Stroehlein. 1977. Relation of solute and sorbed boron to the boron hazard in irrigation water. Plant \& Soil 47;253-256.

Snedecor, G.W. and W.G. Cochran. 1989. Statistical methods. 8th ed. Iowa State Univ., Ames.

Sturgeon, R.J. 1990. Monosaccharides, p. 1-37. In: P.M. Dey (ed.). Methods in plant biochemistry. vol. 2. Carbohydrates. Academic, New York.

Van de Venter, H.A. and H.B. Currier. 1977. The effect of boron deficiency on callose formation and ${ }^{14} \mathrm{C}$ translocation in bean (Phaseolus vulgari.s L.) and cotton (Gossypium hirsutum L.). Amer. J. Bot. 64:861-865.

Weimberg, R. 1987. Solute adjustments-in leaves of two species of wheat at two different stages of growth in relation to salinity. Physiol. Plantarum 70:381-388.

Wilcox, L.V. 1948. The quality of water for irrigation use. U.S. Dept. Agr. Tech. Bul. 962. 